\title{
A powerful history told badly
}

\author{
Nadine Silva
}

University of Technology Sydney, Faculty of Arts and Social Sciences, PO Box 123, Ultimo NSW 2007, Australia. Nadine.N.Silva@student.uts.edu.au

\begin{abstract}
You wouldn't buy a ticket to a movie if the trailer was awful, right? Therefore, when non-Indigenous people only catch superficially boring glimpses of Aboriginal History, it's no surprise they grow apathetic towards learning more. This essay explores why a powerful history is still being told so badly.
\end{abstract}

Key words: Aboriginal history; Australian history; education; white privilege; white guilt

It's been 50 years since W.E.H. Stanner shined a spotlight on 'The Great Australian Silence', marking a turning point in Australian History. Stanner contended that the country's sense of its own past had been constructed on culture of overlooking:

It is a structural matter, a view from a window which has been carefully placed to exclude a whole quadrant of the landscape. What may have begun as a simple forgetting of other possible views turned under habit and over time into something like a cult of forgetfulness practised on a national scale. (Stanner 1969, p. 25)

By amplifying the volume of this silence, Stanner can be credited for inspiring a deeper interrogation of Australia's one-sided history. However, while his lecture, the 1967 Referendum, the Bringing Them Home Report and the Apology to the Stolen Generations have served as signs of a country engaging with its dark past, many Australians still know so little about Aboriginal History (Cheetham 2015). In a lot of ways, it is still a structural matter. When it comes to Aboriginal History, Australia has time and time again been shown bad trailers to a powerful story. As if the trailers have been edited to show only the parts where the protagonists are helplessly abused; without snippets that portray the depth of the main characters or their resilience to overcome conflict. While Aboriginal history is not a fictional motion picture, this essay argues that its poor storytelling, largely at the hands of non- 
Indigenous people, have compromised the country's interest in unpacking the chronicles of the world's oldest civilization (Devlin 2016). Synthesising analyses of how Aboriginal History has been taught, this essay will explore the underlying social and political factors that continue to stand in the way of an overdue restructuring of history-telling.

\section{Aboriginal people still viewed as subjects, not agents}

In journalism, the 'hook' is referred to as the audience's first contact with a story. It's carefully placed at the beginning of a story to draw people in, essentially 'hooking' them to see the whole thing through. It is estimated that 60 percent of non-Indigenous Australians have never met an Indigenous person (Never Met An Indigenous Person 2017), which means most non-Indigenous people are likely to have their first contact with Indigenous stories within the education system. In a widespread survey of how Aboriginal History is taught in classrooms, students almost unanimously admitted to being bored out of their brains (Clark 2008, p. 66). Their collective disinterest is rooted in the repetition throughout their schooling experience of an emphasis on cultural tools and activities. One student described her experience as 'this is like clapping sticks . . . this is a didgeridoo, and that got a bit tiresome' (Clark 2008, p. 67). The students felt apathetic towards Aboriginal history after being bombarded with hunting tools, common tribes, dreamtime stories and other facets of perceived 'Aboriginal lifestyle' (Clark 2008, p. 66-68). Even Anna Clark determined that these dimensions of culture fell short of the complexities and depth that qualify as an allencompassing history (Clark 2008, p. 67). In a sense, Aboriginal History-teaching is still stuck in Australia's early colonial era of viewing Aboriginal people as savages; subjects to be 'discussed, considered or studied' as opposed to agents that 'produce effect or change' (Cambridge Dictionary 2019). A teacher from Sydney said, 'we visit museums, like the city museum, and we have the people talking to them. And we see the artefacts, performances and so forth. But that really sort of is Aboriginality "on show", isn't it, rather than coming to a real understanding' (Clark 2008, p. 81). Imagine being introduced to Ned Kelly or the Anzacs with the establishment of what a gun is or why damper was so important. It would hardly serve to hook people into the tales of Australia's favourite outlaw or the mateship that carried Australian soldiers through a war. Therefore, it is unsurprising that Australian students disengage with Aboriginal History when its taught without stories of Indigenous agency.

While Ned Kelly and the Anzacs are celebrated in public memory, iconic black outlaws like Jandamarra, and Pemulwuy are marginalised in Australia's history (Smith 2018, Bailey \& Brawley 2018). The frontier conflicts are raised in no depth; stories of the extent that First Nations People went to in order to 'protect and defend' their land remain unmentioned to the masses (Bailey \& Brawley 2018, p. 25). The introduction to the idea that the frontier conflict 'could be termed war' was, for many students, their first introduction to the notion of Indigenous agency (Bailey \& Brawley 2018, p. 24). Upon learning about the frontier wars, a student from Sydney related the motifs of Indigenous people who fought for their land as parallel to 'what we do at war today' (Bailey \& Brawley 2018, p. 25). Students often had preconceived ideas that Aboriginal people simply 'gave into white settlement' or that the 
frontier wars only really troubled the 'first few decades of colonisation' (Bailey \& Brawley 2018 , p. 24). While essential to the nation's formation, these series of conflicts are still yet to be deemed worthy of a feature at the Australian War Memorial (Bailey \& Brawley 2018). The exclusion of the frontier wars by the AWM plays into a national resistance to perspectives of Indigenous agency and a commitment to maintaining the illusion that 'they just gave into white settlement' (Bailey \& Brawley 2018, p. 24). Some students felt that the limited knowledge of the frontier wars are results of an intentional 'attempt to gloss over our darker side and only embrace the good points' (Bailey \& Brawley 2018, p. 28). There were common notions that history in the classroom had been politicized, and that the AWM's absence of the frontier wars contributed to the 'whitewashing of Australian history' (Bailey $\&$ Brawley 2018, p. 29). Even in the reconciliation narrative, Reynold has discerned how the frontier wars had been left out 'for fear of alienating white Australians' (Bailey \& Brawley 2018, p. 30).

\section{The discourse between white guilt and white privilege}

Grappling with the contentious task of explaining white privilege, Briggs, a well-known Indigenous Australian artist describes white privilege as the opportunity of having choices (Günsberg 2019). In unpacking this privilege of choices, Briggs' most insightful analogy reveals that even the concept of time travel is a white privilege (Günsberg 2019). What era of history doesn't serve white people? If a time machine landed in the hands of Indigenous person, why would they want to travel back to a time when they weren't being counted in the census, or when their families were being ripped apart, placed in missions or being executed in the masses (Günsberg 2019). When it comes to history, white people have also had the privilege of choosing what bits to include and leave out. To their benefit, their stories have been told from their own perspectives. If white people don't want to engage with Indigenous history, they have the privilege of not fully immersing in it. For Indigenous people, the ongoing effects of Aboriginal History is a lived experience, one they don't have the privilege of choosing not to know. One student described his kindergarten to year 12 history experience as a 'succession of Gold Rushes, Eureka Stockades, Ned Kelly and brave settlers' (Bailey \& Brawley 2018, p. 26). It is a testimony to the fact that Australian history has been constructed from the perspective of white struggles. It has privileged 'the hardship faced by Europeans over that experienced by the country's original inhabitants' which allows the perceived significance of settlement to mask acts of violence (Bailey \& Brawley 2018, p. 26).

Today, the guilt of white people is continuing to be privileged over the telling of an allencompassing and uncensored two-sided history. Clark's research provides an insight into the reason more people have left Aboriginal History untapped. Among the number of students who weren't afraid to say they didn't want to feel guilty about their past, one in particular declared, 'it's kind of bad enough that we're the convict country. . . but when it's drilled into us that we killed everything good in this country, it's like not fun' (Clark 2008, p. 70). This suppression of guilt is echoed in political sentiments of the time, when John Howard told Australia that 'history should never be a source of smug delusions or comfortable superiority, 
but nor should it be a basis for obsessive and consuming national guilt and shame (Clark 2008, p. 71). Even the notions of superiority, guilt and shame are those prescribed to the white population. They are privileged over Indigenous calls for truth-telling, reconciliation and healing which aren't even mentioned. Essentially, white privilege is also having the opportunity to choose not to feel guilty at the expense of suppressing the Aboriginal side of Australian history.

\section{Curriculum change is easier said than done}

'Waves of new historical writing' emerged in the 1960s and 70s to 'fill the silence' that Stanner brought attention to (Clark 2008, p. 73). The growing value of Indigenous perspectives snowballed into a shift in history teaching in the 1970s and 80s (Clark 2008, p. 73). Within one generation, Australian history was radically renovated to include Indigenous perspectives (Clark 2008, p. 73). However, scrutiny of the revised curriculum in the period of 1991-94 reveal that expectations were high as 'restructured and shifting educational environment shaped this period', but resources were insufficient to see these changes through (Land 1994, p. 9). Not to mention, teachers were then tasked with teaching a history they hadn't learnt themselves (Clark 2008, p. 72-73). A respondent in Clark's research identified four issues as affecting the teaching of Aboriginal curriculum: preconceived ideas of teachers' and students', the teacher's interest in the subject, school culture and time management (Bailey \& Brawley 2018, p. 26).

Not to mention, the updated curriculum was designed to progressively develop a deeper knowledge of history (Clark 2008, p. 79). Ideally, as the topics advance, 'students revisit them in different and increasingly complex ways' (Clark 2008, p. 79). However, in practise, this approach is challenging to organise as children progress through different 'year levels, teachers and schools' (Clark 2008, p. 78). The reality is, they rarely have the same background knowledge because specific content is seldom prescribed in the framework (Clark 2008, p. 78). The lack of consistency and structure of the curriculum means that by the time they finish school, 'most students in Australian schools will have experienced a fragmented, repetitive and incomplete picture of their national history' (Clark 2008, p. 77). It's like intending to give a group of people the same book to read, except each individual book has its chapters shuffled in different orders, paragraphs and even chapters are missing at random, occasionally there are two of the same chapters in the one book. It's as illogical as the incoherent structure itself to expect that each person would reach the same wholistic understanding of the full story by the time they get to the end.

\section{Fear of speaking for Aboriginal people}

On top of the illogical curriculum structure of Aboriginal history, the fear of speaking for Aboriginal people is another reason content is repetitively taught (Clark 2008, p. 80).

Teachers fear that 'by speaking for Aboriginal people, they may in fact be maintaining the very silence they hoped to overturn' (Clark 2008, p. 81). Therefore, they continue to teach 
what feels safe; the parts they feel is appropriate for them to teach (Clark 2008, p. 81). One teacher from Canberra said, 'I've tried to get in Indigenous guest speakers because I feel more comfortable with them telling their own story than me - that's not because I think I don't understand, I just think it's important' (Clark 2008, p. 81). However, when Aboriginal and Torres Strait Islander people make up less than $3 \%$ of the population, ensuring an Indigenous voice is present in every classroom is unrealistic (Australian Bureau of Statistics 2018). A lack of resources and the fear of being culturally inappropriate can even be attributed to the reason that students feel like they have watched the Rabbit Proof Fence too many times throughout their schooling career (Clark 2008, p. 81).

This fear is validated by incidents where non-Indigenous people teach Indigenous history with good intentions but fall short of cultural sensitivity in their approach. Earlier this year, Griffith University was accused of teaching Indigenous history with a pro-mission bias (Griffith University accused of teaching Indigenous studies with a pro-mission bias 2019). The lecturer, a German woman, was teaching the cohort about the benefits of German missions to Aboriginal people (Griffith University accused of teaching Indigenous studies with a pro-mission bias 2019). A student named Andrew Beitzel, a descendant of the Stolen Generations whose grandparents grew up on missions, took particular offence to the absence of Aboriginal perspectives and the lack of acknowledgement that missions, no matter how good their intentions, contributed to a cultural genocide (Griffith University accused of teaching Indigenous studies with a pro-mission bias 2019). After his activism was covered by the media, this incident led to the stepping down of that lecturer. This experience is comparable to that of a teacher at Central Australia. When she related one massacre to another that took place locally, the disagreement of what happened hit a few nerves in the classroom (Clark 2008, p. 82). She said, 'I realised that without knowing I touched on something I shouldn't have touched on' (Clark 2008, p. 82).

\section{Conclusion}

This cocktail of challenges perpetuates the mainstream idea that learning more about Aboriginal History would mean that non-Indigenous people would have to engage with more stories entailing the atrocities their ancestors inflicted onto Aboriginal people. This idea highlights the fact that Aboriginal agency has been largely missing from the historical narrative; the notion of Indigenous agency is therefore absent in people's minds when they attempt to conceive the parts of history they don't know. It reflects the perpetuating historical comprehension of Aboriginal people as subjects, and not agents. Contributing to the dismissal of knowing more is a complex discourse between white guilt and white privilege, and an incoherent school curriculum that leaves students feeling uninspired to learn more. As a teacher from Brisbane reiterated 'it's not a particular perspective. It's simply a dimension of the whole, and it can't be overlooked' (Clark 2008, p. 83). Until a wholistic, complex, twosided, structured history is made available to Australian classrooms, the country will continue to be happy with what little they know (Clark 2008), in the same way you would be content with not buying tickets to a movie after seeing a bad trailer. 


\section{Reference List}

Australian Bureau of Statistics 2018, 2071.0 - Census of Population and Housing: Reflecting Australia - Stories from the Census, 2016, Canberra, viewed 21 June 2019,

<https://www.abs.gov.au/ausstats/abs@.nsf/Lookup/by\%20Subject/2071.0 2016 Main\%20F eatures Aboriginal \%20and\%20Torres \%20Strait\%20Islander\%20Population\%20Data\%20Su mmary $\sim 10>$.

Bailey, M. \& Brawley, S. 2019, 'Why Weren't We Taught? Exploring Frontier Conflict Through the Lens of Anzac', Journal of Australian Studies, vol. 42, no. 1, pp. 19-33.

Cambridge Dictionary 2019, Cambridge University Press, Cambridge, viewed 21 June 2019, $<$ https://dictionary.cambridge.org/dictionary/english/agent $>$.

Cambridge Dictionary 2019, Cambridge University Press, Cambridge, viewed 21 June 2019, $<$ https://dictionary.cambridge.org/dictionary/english/subject>.

Cheetham, D. 2015, 'Young and free? Why I declined to sing the national anthem at the 2015 AFL Grand Final', The Conversation, 20 October, viewed 21 June 2019, $<$ https://theconversation.com/young-and-free-why-i-declined-to-sing-the-national-anthem-atthe-2015-afl-grand-final-49234> .

Clark, A. 2008, '1788 and all that', History's Children: History wars in the classroom, UNSW Press, Randwick, pp. 64-88.

Devlin, H. 2016, 'Indigenous Australians most ancient civilisation on Earth, DNA study confirms', The Guardian, 22 September, viewed 21 June 2019,

$<$ https://www.theguardian.com/australia-news/2016/sep/21/indigenous-australians-mostancient-civilisation-on-earth-dna-study-confirms>.

Griffith University accused of teaching Indigenous studies with a pro-mission bias 2019, radio program, The Wire, 2SER 107.3 FM, Sydney, 1 April.

Günsberg, O. 2019, 'The power of self-belief, racism, and coffee with Briggs', The Osher Günsberg Podcast, audio podcast, Acast, 12 May, viewed 21 June 2019, $<$ https://play.acast.com/s/the-osher-gunsberg-podcast/18a87903-7fdb-49aa-abe7$0 \mathrm{dec} 4 \mathrm{~d} 6 \mathrm{c} 009 \mathrm{c}>$.

Land, R. 1994. 'Furore over Invasion Text': Introduction to the Politics, Process and Players', Invasion and After: A Case Study in Curriculum Politics, Queensland Studies Centre, Brisbane, pp. 1-11.

Never Met An Indigenous Person 2017, video recording, ABC, Ultimo. 
Smith, E. 2018, 'Jandamarra: The outlaw who fought to save his country and people from colonisation', ABC Kimberley, 4 July, viewed 21 June 2019,

$<$ https://www.abc.net.au/news/2018-07-04/iconic-australian-landscape-home-to-fiercewarrior/9936054>.

Stanner, W.E.H. 1969, 'The Great Australian Silence', the 1968 Boyer Lectures: After The Dreaming, Sydney, ABC Enterprises, pp 18-29. 